\title{
Pd(II) Metal Coordination-driven Isomerically Preorganized Receptors with the Enhanced Affinity for Aromatic Carboxylates in Water
}

\author{
Choon Woo Lim* and Jong-In Hong ${ }^{\dagger, *}$ \\ Department of Applied Chemistry, College of Applied Science, Kyung Hee University, Gyeonggi-do 449-701, Korea \\ ${ }^{*}$ E-mail: choonwoo.lim@khu.ac.kr \\ †Department of Chemistry, College of Natural Sciences, Seoul National University, Seoul 151-747, Korea \\ *E-mail: jihong@snu.ac.kr
}

Received December 8, 2010, Accepted December 28, 2010

Key Words : Pd-coordination, Preorganization, Aromatic carboxylates, Cooperativity

Preorganization of synthetic receptor has recently received much attention in the molecular recognition research fields. As a model system for mimicry of biological events in relation to specific substrate recognition, various synthetic receptors based on calix[4]arene, ${ }^{1}$ resorcin[4] $\operatorname{arene}^{2}$ and foldamer structures ${ }^{3}$ have been extensively employed for the research of molecular recognition, presenting strong complex formation for specific guests including anionic species $^{1 \mathrm{c}, 4}$ and biomolecules. ${ }^{5}$ In particular, water-soluble receptor attracts much attention in the molecular recognition, since significant biological events are mediated or triggered by specific substrate-receptor recognition in the aqueous media and it is very important to develop a preorganized structure of proteins for understanding the selective protein-substrate binding behaviors at the molecular level. ${ }^{6}$ The concept of preorganization is very crucial in the design and synthesis of artificial receptor, stabilizing substrate-receptor complex as well as the structure of receptor. ${ }^{7}$ Preorganization of artificial receptors has been produced via covalent synthetic methods ${ }^{8}$ and noncovalent interactions including hydrogen bonding ${ }^{9}$ and metal coordination. ${ }^{10}$ Previously, we have reported the preparation of water soluble receptor based on resorcin[4]arene, ${ }^{11}$ which was preorganized through intramolecular Pd complexation in water and thus showed more than ten times enhanced affinities for proper anionic guests in ${ }^{1} \mathrm{H}$ NMR titrations. Herein we present molecular recognition of the isomerically preorganized receptors in aqueous media, which are inspired

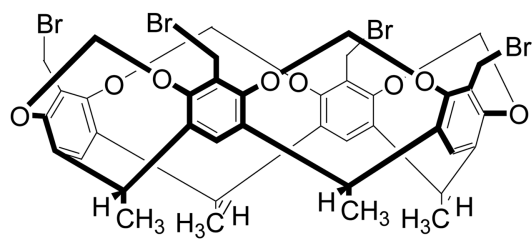

1

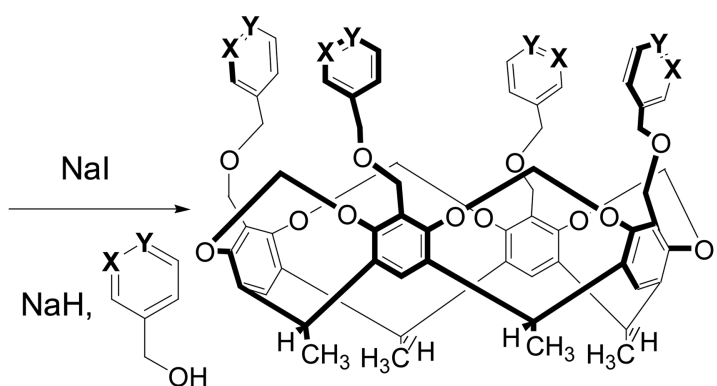

2a: $X=N, Y=C$

2b: $X=C, Y=N$

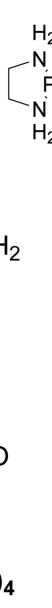<smiles>N[P+](N)(=O)ON(O)O[Na]</smiles><smiles></smiles>

.


from the previous reports. ${ }^{10 a, 11}$ In the context, water-soluble isomeric receptors with significantly different affinity for benzene carboxylate derivatives are elaborately discussed in relation to the preorganization concept.

Ligand molecules 2 were synthesized following the procedure as presented in Scheme 1. Nucleophilic substitutions of tetrabromomethyl-substituted resorcin[4]arene with hydroxylmethyl pyridine in the presence of sodium hydride afforded the desired ligands $\mathbf{2 a}{ }^{11}$ and $\mathbf{2 b} .^{12}$ Structural isomer, 3- and 4-hydroxymethyl pyridines were employed for the formation of isomerically preorganized structure. Receptors $\mathbf{3} \mathbf{a}^{11}$ and $\mathbf{3} \mathbf{b}^{13}$ are formed by coordination of cisprotected $\mathrm{Pd}(\mathrm{II})$ metal complex $\mathrm{Pd}(\mathrm{en})\left(\mathrm{NO}_{3}\right)_{2}$ with $m$ - and $p$ pyridyl groups appended on resorcinarene respectively and ESI MS spectra have confirmed the formation of water soluble receptors by intramolecular Pd complexations. ${ }^{11,13}$ (See Fig S2 in supplementary data for $\mathbf{3 b}$ ) Scheme 1 shows the synthesis of the preorganized Pd(II) complex structures. "cis-protected" Pd dications are employed for preorganization of binding site and its ionic character is also functioned as a cooperative binding motif.

Structural features of each isomeric receptor are precisely elucidated by ${ }^{1} \mathrm{H}$ NMR and HH COSY spectra. Figure 1 shows ${ }^{1} \mathrm{H}$ NMR spectra of two cognate receptors. Pd(II) coordinations with pyridyl groups lead to $C_{2 \mathrm{v}}$ symmetrical features and results in the splitting of bridge protons $\left(H_{\text {in }} /\right.$ $H_{\text {in' }}$ and $\left.H_{\text {out }} / H_{\text {out }}\right)$ on the upper rim of resorcin[4]arene in ${ }^{1} \mathrm{H}$ NMR spectra. The bridge protons are divided into outer $\left(H_{\text {out }}\right)$ and inner protons $\left(H_{\text {in }}\right)$, which point outward and inward the cavity of resorcin[4]arene respectively. Figure 1 shows the highly upfield shifted bridge protons $\left(H_{\mathrm{in}^{\prime}}\right.$ and $\left.H_{\text {out }}\right)$ and this clearly indicates these protons $\left(H_{\text {out }}\right.$ and $\left.H_{\text {in }}\right)$ experience shielding effect by two pyridyl groups organized by $\mathrm{Pd}(\mathrm{II})$ complexation. Although two receptors are isomerically preorganized and seem to show similar structural features, it is interesting to note signals of outer protons $\left(\mathrm{H}_{\text {out' }}\right)$ of $\mathbf{3} \mathbf{b}$ are higher upfield-shifted than those of $\mathbf{3 a}$ in ${ }^{1} \mathrm{H}$ NMR spectra, implying the shielded region of pyridyl group in $\mathbf{3 b}$ is closer to the bridge protons and folded out open to the outside surface of resorcin[4]arene rims. HH COSY spectrum confirmed the assignments of ${ }^{1} \mathrm{H}$ NMR for the bridge protons on the upper rims of resorcin[4]arene. (See Fig S1 in supplementary data)

${ }^{1} \mathrm{H}$ NMR titrations were performed and various benzene carboxylate derivatives were employed to investigate binding affinity of two cognate receptors with an isomerically preorganized binding site. We screened benzene carboxylate derivatives with the same substituted position and different degree of electron density. It is worthwhile to note that electron-rich aromatic compounds such as $m$-toluic acid and $m$-anisic acid sodium salts are more strongly bound compared to the electron-deficient aromatic anionic guests such as $m$-cyanobenzoic acid and $m$-nitrobenzoic acid sodium salts. Both receptors $\mathbf{3 a}$ and $\mathbf{3} \mathbf{b}$ show identical trends of binding affinity to guests, indicating the association events might be driven by same attractive forces. These affinity trends to aromatic anionic guests probably result from the

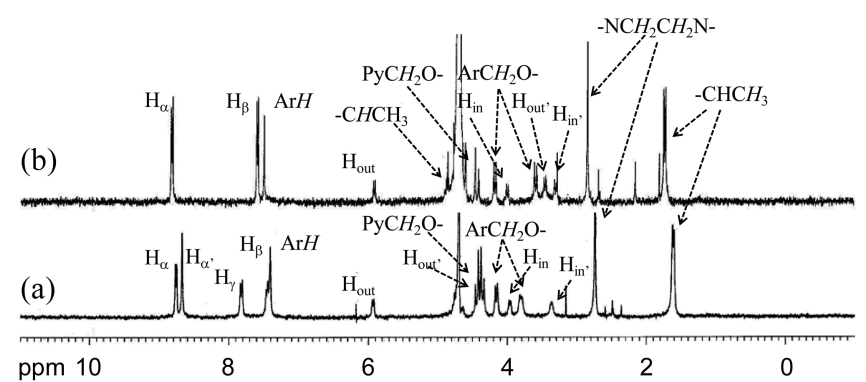

Figure 1. ${ }^{1} \mathrm{H}$ NMR $\left(300 \mathrm{MHz}, \mathrm{D}_{2} \mathrm{O}\right)$ spectra of (a) receptor 3a and (b) receptor $\mathbf{3 b}$.

hydrophobic cavity of $\mathbf{3 a}$ and $\mathbf{3 b}$ with the electron-poor environment generated by the coordinated pyridyl groups with Pd(II) metal dication.

Although the two receptors possess isomeric structures, $\mathbf{3 a}$ shows 2 to 5 fold higher binding affinities for the carboxylates guests than $\mathbf{3 b}$. The preorganized binding site of receptor 3a seems to be better fit for inclusion of benzene carboxylate derivatives, compared to receptor $\mathbf{3} \mathbf{b}$, although they have the same skeleton of binding site with similar electron deficiency. Since Pd(II) coordinations preorganize hydrophobic binding site with positively charged motif which is electrostatically interacted with aromatic anionic guests, receptor 3a is structurally considered to generate more effective cooperative binding site for benzene carboxylates derivatives. Preorganization control of binding site, which potentially acts as cooperative forces, is necessary for enhancing the ability of receptor to recognize benzene carboxylate derivatives. In addition, aromatic carboxylates substituted with alkoxy moiety properly reside inside the resorcinarene hydrophobic cavity and show larger binding constants compared to other aromatic carboxylates. The association constant between 3a and 3-ethoxy benzene carboxylate in $\mathrm{D}_{2} \mathrm{O}$ was too large to be measured accurately by ${ }^{1} \mathrm{H}-\mathrm{NMR}$ titrations and was obtained in methanol-water mixed solvents, expecting the reduced hydrophobic interaction. The binding constant turned out to be $50,000 \mathrm{M}^{-1}$ even in the mixed solvent system $\left(\mathrm{D}_{2} \mathrm{O} / \mathrm{CD}_{3} \mathrm{OD}, 19: 1, \mathrm{v} / \mathrm{v}\right)$. Also guests such as benzoic acid sodium salt, 3-toluic acid sodium salt and 3-methoxy benzoic acid sodium salt showed smaller binding constants in mixed solvent system $\left(\mathrm{D}_{2} \mathrm{O} /\right.$ $\mathrm{CD}_{3} \mathrm{OD}, 19: 1, \mathrm{v} / \mathrm{v}$ ) than in $\mathrm{D}_{2} \mathrm{O}$. It is thought that aromatic alkyl moiety of an appropriate length shows the effective cooperative binding events in the preorganized cavity of receptor $3 \mathbf{a}$.

To elucidate thermodynamic parameters controlling the complexation process, temperature-dependent ${ }^{1} \mathrm{H}-\mathrm{NMR}$ titrations were performed to give the van't Hoff plot between 3a and $m$-toluic acid sodium salt (Figure 2) and it is shown that the complexation process is enthalphically favored $\left(\Delta \mathrm{H}^{\mathrm{o}}=-8.13 \mathrm{kcalmol}^{-1}\right)$ and entropically less favored $\left(\Delta \mathrm{S}^{\mathrm{o}}\right.$ $=-8.3 \mathrm{calK}^{-1} \mathrm{~mol}^{-1}$ ). Enthalphically favorable process indicates the electrostatic interactions as well as hydrophobic interactions might contribute to the binding of aromatic carboxylate anionic guests. 
(a)

\begin{tabular}{ccccc}
\hline Slope & Intercept & $\begin{array}{c}\Delta H^{\mathrm{o}} \\
(\mathrm{kcal} / \mathrm{mol})\end{array}$ & $\begin{array}{c}\Delta S^{\mathrm{o}} \\
(\mathrm{cal} / \mathrm{molK})\end{array}$ & $\begin{array}{c}\Delta G^{\circ}(300 \mathrm{~K}) \\
(\mathrm{kcal} / \mathrm{mol})\end{array}$ \\
\hline 4.091 & -4.18 & -8.13 & -8.3 & -5.64 \\
\hline
\end{tabular}

(b)

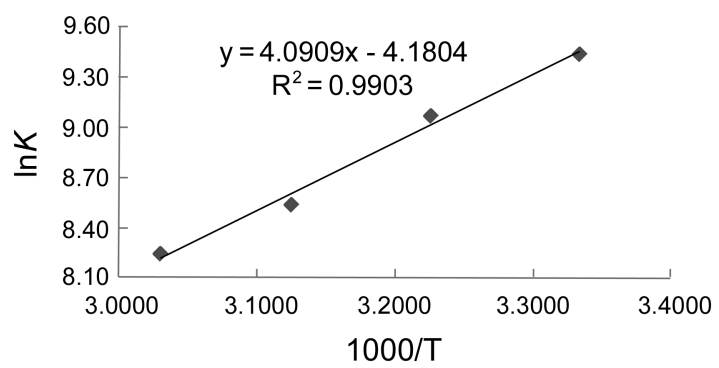

Figure 2. Thermodynamic parameters (a) and van't Hoff plot (b) of binding process of receptor 3a for 3-methyl benzene carboxylate.

Table 1. Binding constants $\left(\mathrm{M}^{-1}\right)$ of the $1: 1$ host-guest complexes in $\mathrm{D}_{2} \mathrm{O}^{a}$

\begin{tabular}{|c|c|c|c|c|c|c|}
\hline $3 \mathbf{a}$ & 160 & 210 & $\begin{array}{c}1040 \\
(210)^{b}\end{array}$ & $\begin{array}{c}12600 \\
(1100)^{b}\end{array}$ & $\begin{array}{c}100000 \\
(31000)^{b}\end{array}$ & $(50000)^{b}$ \\
\hline $\mathbf{3 b}$ & & & 260 & 2800 & 40000 & \\
\hline
\end{tabular}

${ }^{a}$ Binding constants were obtained by ${ }^{1} \mathrm{H}$ NMR titrations on the basis of the $1: 1$ binding model at $300 \mathrm{~K} .{ }^{b}$ binding constants in $\mathrm{D}_{2} \mathrm{O} / \mathrm{CD}_{3} \mathrm{OD}(19 /$ 1). All counterions are $\mathrm{Na}^{+}$.

In conclusion, we have synthesized water soluble molecular receptors 3 and $\mathrm{Pd}(\mathrm{II})$ metal coordination preorganizes a hydrophobic binding site with positively charged binding motif. The preorganized binding site of isomeric receptors 3 produces an electron-deficient hydrophobic environment and shows a high binding affinity to "electron-rich" aromatic carboxylate anions. Two isomeric receptors show significant differences of binding affinity for benzene carboxylate derivatives, demonstrating the preorganized binding site with the complementarity-sized and geometrically matched frameworks should be precisely designed for enhancing binding affinity of receptor in water.

Acknowledgments. This study was supported by the National Research Foundation of Korea (NRF) funded by the Ministry of Education, Science and Technology (grant no: 2008-314-1-C00206).

\section{References}

1. (a) Scheerder, J.; van Duynhoven, J. P.; Engbersen, J. F. J.; Reihoudt, D. N. Angew. Chem. Int. Ed. 1996, 35, 1090. (b) Pelizzi, N.; Castani, A.; Friggeri, A.; Ungaro, R. J. Chem. Soc., Perkin Trans. 2 1998, 1307. (c) Arnaud-Neu, F.; Collins, E. M.; Deasy, M.; Ferguson, G.; Harris, S. J.; Kaitner, B.; Lough, A. J.; Mckervey,
A.; Marques, E.; Ruhl, B. L.; Schwing-Weill, M. J.; Seward, E. M. J. Am. Chem. Soc. 1989, 111, 8681.

2. (a) Schneider, H.-J.; Guttes, D.; Schneidr, U. Angew. Chem. Int. Ed. 1986, 25, 647. (b) Yoon, J.; Cram, D. J. Chem. Commun. 1997, 497. (c) Fraiser, J. R.; Borecka, B.; Trotter, J.; Sherman, J. C. J. Org. Chem. 1997, 60, 1207.

3. (a) Gellman, S. H. Acc. Chem. Res. 1998, 31, 173. (b) Juwarker, H.; Suk, J.-M.; Jeong, K.-S. Chem. Soc. Rev. 2009, 38, 3316. (c) Wu, Z.-Q.; Shao, X.-B.; Li, C.; Hou, J.-L.; Wang, K.; Jiang, X.-K.; Li, Z.-T. J. Am. Chem. Soc. 2005, 127, 17460.

4. (a) Sessler, J. L.; Gale, P. A.; Cho, W.-S. Anion Receptor Chemistry; Royal Society of Chemistry: Cambridge, UK, 2006. (b) Davis A. P. Coord. Chem. Rev. 2006, 250, 2918. (c) Schmidtchen, F. P. Coord. Chem. Rev. 2006, 250, 2918. (d) Kwon, T. H.; Jeong, K.-S. Tetrahedron Lett. 2006, 47, 8539.

5. (a) Park, C. E.; Jung, Y. G.; Hong, J.-I. Tetrahedron Lett. 1998, 39, 2353. (b) Kim, J.; Raman, B.; Ahn, K. H. J. Org. Chem. 2006, 71, 38. (c) Bell, T. W.; Liu, J. J. Am. Chem. Soc. 1988, 110, 3673.

6. (a) Myers, J.; Oas, T. G. Nature Struct. Biol. 2001, 8, 552. (b) Noeske, J.; Buck, J.; Fürtig, B.; Nasiri, H. R.; Schwalbe, H.; Wöhnert, J. Nucleic Acids Res. 2007, 35, 572. (c) Maglio, O.; Nastri, F.; Pavone, V.; Lombardi, A.; DeGrado, W. F. Proc. Natl. Acad. Sci. USA 2003, 100, 3772.

7. (a) Reinhoudt, D. N.; Dijkstra, P. J. Pure. Appl. Chem. 1988, 60, 477. (b) Horiuchi, N.; Huff, J. Rebek, J. Tetrahedron Lett. 1990, 31,5121 .

8. (a) Filby, M. H.; Humphries, T. D.; Turner, D. R.; Kataky, R.; Kruusma, J.; Steed, J. W. Chem. Commun. 2006, 156. (b) Lascaux, A.; Gac, S. L.; Wouters, J.; Luhmer, M.; Jabin, I. Org. Biomol. Chem. 2010, 8, 4607. (c) Li, Y.; Flood, A. H. Angew. Chem. Int. Ed. 2008, 47, 2649. (d) Chimielewski, M. J.; Jurczak, J. Chem. Eur. J. 2006, 12, 7652.

9. (a) Liu, H.; Wu, J.; Xu, Y.-X.; Jiang, X.-K.; li, Z.-T. Tetrahedron Lett. 2007, 48, 7327. (b) Zhao, X.; Li, Z.-T. Chem. Commun. 2010, 46, 1601. (c) Lee, S.; Hua, Y.; Park, H.; Flood, A. H. Org. Lett. 2010, 12, 2100. (d) Kim, H-J.; Kim, H.; Jeong, E. J.; Thavarajah, N.; Studnicki, L.; Koprianiuk, A.; Lough, A. J.; Suh, J.; Chin, J. J. Am. Chem. Soc. 2005, 127, 16370.

10. (a) Park, S. J.; Shin, D. M.; Sakamoto, S.; Yamaguchi, K.; Chung, Y. K.; Lah, M. S.; Hong, J.-I. Chem. Commun. 2003, 998. (b) Wang, Y.; Duran, E.; Nacionales, D.; Valencia, A.; Wostenberg, C.; Marinez, E. R. Tetrahedron Lett. 2008, 49, 6410. (c) Kim, H.-J.; Kim, W.; Lough, A. J.; Kim, B. M.; Chin, J. J. Am. Chem. Soc. 2005, 127, 16776.

11. Lim, C. W.; Hong, J.-I. Tetrahedron Lett. 2000, 41, 3113.

12. Selected spectral data for $\mathbf{2 b}:{ }^{1} \mathrm{H}$ NMR (300 MHz, $\left.\mathrm{CDCl}_{3}\right) ; \delta 8.56$ $\left(\mathrm{d}, J=5.9 \mathrm{~Hz}, 8 \mathrm{H}, \operatorname{Py} \boldsymbol{H}_{\alpha}\right), 7.28(\mathrm{~s}, 4 \mathrm{H}, \mathrm{Ar} \boldsymbol{H}), 7.23(\mathrm{~d}, J=5.8 \mathrm{~Hz}$, $\left.8 \mathrm{H}, \mathrm{Py} \boldsymbol{H}_{\beta}\right), 5.74$ (d, $\left.J=7.0 \mathrm{~Hz}, 4 \mathrm{H}, \operatorname{ArOCH}_{\text {out }} \mathrm{H}_{\text {in }} \mathrm{OAr}\right), 5.01$ (q, $J$ $=7.4 \mathrm{~Hz}, 4 \mathrm{H}, \mathbf{C} \boldsymbol{H C H})_{3}, 4.50\left(\mathrm{~s}, 8 \mathrm{H}, \mathbf{P y C H}_{2} \mathrm{O}\right), 4.32(\mathrm{~s}, 8 \mathrm{H}$, $\left.\operatorname{ArCH}_{2} \mathrm{O}\right), 4.29\left(\mathrm{~d}, J=7.1 \mathrm{~Hz}, 4 \mathrm{H}, \mathrm{ArOCH}_{\text {out }} \boldsymbol{H}_{\text {in }} \mathrm{OAr}\right), 1.76(\mathrm{~d}, J=$ $7.4 \mathrm{~Hz}, 12 \mathrm{H}, \mathrm{CHCH})_{3}$.

13. ${ }^{13} \mathrm{C}$ NMR (75 MHz, $\left.\mathrm{CDCl}_{3}\right) \delta 154.0,150.1,147.4,139.3,123.5$, $122.9,120.7,99.8,71.6,62.9,31.5,16.4$; FAB-MS (NBA, $m / z)$; $1077\left(\mathrm{M}+\mathrm{H}^{+}\right)$.

14. Selected spectral data for $\mathbf{3 b}:{ }^{1} \mathrm{H}$ NMR $\left(300 \mathrm{MHz}, \mathrm{D}_{2} \mathrm{O}\right) ; \delta 8.87$ $\left(\mathrm{d}, J=6.1 \mathrm{~Hz}, 8 \mathrm{H}, \operatorname{Py} \boldsymbol{H}_{\alpha}\right), 7.64$ (d, $\left.J=6.2 \mathrm{~Hz}, 8 \mathrm{H}, \operatorname{Py} \boldsymbol{H}_{\beta}\right), 7.55$ (s, $J, 4 \mathrm{H}, \mathrm{Ar} \boldsymbol{H}), 5.98\left(\mathrm{~d}, J=7.2 \mathrm{~Hz}, 2 \mathrm{H}, \operatorname{ArOC} \boldsymbol{H}_{\text {out }} \mathrm{H}_{\mathrm{in}} \mathrm{OAr}\right), 4.92$ (q, $\left.J=6.0 \mathrm{~Hz}, 2 \mathrm{H}, \mathrm{C} \boldsymbol{H C H})_{3}\right), 4.55$ (q, $J=14.4 \mathrm{~Hz}, 8 \mathrm{H}, \mathrm{PyCH}_{2} \mathrm{O}$; d, $\left.2 \mathrm{H}, \mathrm{ArOCH}_{\text {out }} \boldsymbol{H}_{\text {in }} \mathrm{OAr}\right), 4.23\left(\mathrm{~d}, J=9.2 \mathrm{~Hz}, 4 \mathrm{H}, \operatorname{ArCH}_{\alpha} \boldsymbol{H}_{\beta} \mathrm{O}\right)$, $4.05(\mathrm{~d}, J=7.3 \mathrm{~Hz}), 3.65\left(\mathrm{~d}, J=9.8 \mathrm{~Hz}, 4 \mathrm{H}, \operatorname{ArCH}_{\alpha} \mathrm{H}_{\beta} \mathrm{O}\right), 3.52(\mathrm{~d}$, $\left.J=7.9 \mathrm{~Hz}, 2 \mathrm{H}, \operatorname{ArOC} \boldsymbol{H}_{\text {out }} \mathrm{H}_{\mathrm{in}} \mathrm{OAr}\right) 3.36(\mathrm{~d}, J=9.4 \mathrm{~Hz}, 2 \mathrm{H}$, $\left.\mathrm{ArOCH}_{\text {out }} \boldsymbol{H}_{\text {in }} \cdot \mathrm{OAr}\right), 2.90\left(\mathrm{~s}, 8 \mathrm{H}, \mathrm{NCH}_{2} \mathrm{CH}_{2} \mathrm{~N}\right), 1.79(\mathrm{~d}, J=7.4$ $\left.\mathrm{Hz}, 12 \mathrm{H}, \mathrm{CHCH}_{3}\right)$; ESI-MS $(\mathrm{m} / \mathrm{z}) ; 767\left[\mathrm{M}-2\left(\mathrm{NO}_{3}\right)\right]^{2+}, 703[\mathrm{M}-$ $\left.2\left(\mathrm{NO}_{3}\right)-2 \mathrm{HNO}_{3}\right]^{2+}, 489\left[\mathrm{M}-3\left(\mathrm{NO}_{3}\right)\right]^{3+}, 469\left[\mathrm{M}-3\left(\mathrm{NO}_{3}\right)-\right.$ $\left.\mathrm{HNO}_{3}\right]^{3+}, 351\left[\mathrm{M}-4\left(\mathrm{NO}_{3}\right)\right]^{4+}$. 